\title{
Effects of 16 pure hydrocarbons and two oils on haemocyte and haemolymphatic parameters in the Pacific oyster, Crassostrea gigas (Thunberg)
}

\author{
Anne Bado-Nilles ${ }^{\mathrm{a}, \mathrm{b},{ }^{*}}$, Béatrice Gagnaire ${ }^{\mathrm{c}}$, Hélène Thomas-Guyon ${ }^{\mathrm{a}}$, Stéphane Le Floch ${ }^{\mathrm{b}}$ and \\ Tristan Renault ${ }^{\mathrm{C}}$

\footnotetext{
a LIENSs Littoral ENvironnement et Sociétés UMR 6250 CNRS, Université de La Rochelle 2 rue Olympe de Gouges, 17000 La Rochelle, France

${ }^{\mathrm{b}}$ Cedre, Centre de Documentation de Recherche et d'Expérimentations sur les Pollutions Accidentelles des Eaux, 715 rue Alain Colas, CS 41836, 29218 Brest Cedex 2, France

c Ifremer, Laboratoire de Génétique et Pathologie, Ronce-les-Bains, 17390 La Tremblade, France
} *: Corresponding author : A. Bado-Nilles, Tél: +33-546-500 297; fax: +33-546-500 294, email address
: anne.badonil@yahoo.fr

\begin{abstract}
:
The in vitro effects of polycyclic aromatic hydrocarbons (PAHs) on haemocyte and haemolymphatic parameters of the Pacific oyster, Crassostrea gigas, were tested using field concentrations $\left(10^{-7}\right.$ and $10^{-9} \mathrm{mg} \mathrm{mL}^{-1}$ ) observed in the Marennes-Oleron Basin (Charente-Maritime, France) and high concentrations $\left(10^{-3}\right.$ and $\left.10^{-5} \mathrm{mg} \mathrm{mL}^{-1}\right)$ observed during oil spills. As a first step, the effects of pollutants, after a $24 \mathrm{~h}$ contamination period, were monitored on individual and pooled haemolymph samples and similar results were observed for both sample types. In a second step, haemolymphs from 45 oysters were withdrawn and pooled. Eighteen pollutants were tested in vitro after a 4 and $24 \mathrm{~h}$ contamination period and 10 of them showed significant modulations of the five haemocyte parameters tested. Seven pollutants (fluorene, pyrene, anthracene, phenanthrene, chrysene, indeno[1,2,3-c,d]pyrene and heavy fuel oil (HFO)) induced a decrease in haemocyte mortality. Fluorene, pyrene and HFO significantly decreased phagocytosis activity. Percentage of non-specific esterase positive cells, phenoloxidase activity and lysosome presence were increased by naphthalene, benzo[b]fluoranthene and dibenz[a, $h]$ anthracene, respectively. Modulation of immune parameters in the Pacific oyster by PAHs suggested that PAH pollution may be related to enhanced susceptibility to diseases.
\end{abstract}

Keywords: Haemocyte activity; Flow cytometry; Spectrophotometry; Pacific oyster; PAHs; Toxicity 


\section{Introduction}

Among various chemical contaminants, the pollution caused by polycyclic aromatic hydrocarbons (PAHs) has led over recent years to numerous studies on the origin, distribution and fate of PAHs in the environment. Two main sources are identified: petrochemical (natural seepages, discharges of urban and industrial effluents, offshore oil production and oil spill) and pyrogenical (combustion processes due to human or natural fate). Concerning oil spill inputs, many authors have measured the concentrations of PAHs in the sediment and their effects on aquatic organisms before and after the event (Franco et al., 2006; Law, 1978; Morales-Caselles et al., 2006). These types of concerns were also studied in the case of chronic pollution (Budzinski et al., 1997; Halldorsson et al., 2004; Stehr et al., 2004; Van der Oost et al., 1991). Although many studies deal with PAH contamination of freshwater (Acheson et al., 1976; Tronczynski et al., 2004; WHO, 1997), only few authors have measured concentrations of the dissolved fraction of hydrocarbons in seawater (Boehm et al., 2007; Law, 1978; Maldonado et al., 1999). PAH concentrations following different oil spills ranged from $6.10^{-4} \mathrm{mg} \cdot \mathrm{mL}^{-1}$ after the Exxon Valdez oil spill (Boehm et al., 2007) to $17.10^{-4} \mathrm{mg} \cdot \mathrm{mL}^{-1}$ after the Ekofisk blowout (Law, 1978).

Anthropogenic contaminants, including PAHs, may affect the immunity of aquatic vertebrates (Reynaud et al., 2004; Yamaguchi et al., 1996) and invertebrates (Gagnaire et al., 2006a; Grundy et al., 1996a). Innate immunity in bivalve molluscs relies on haemocytes, the circulating cells present in extrapallial fluids, and haemolymph (Cheng, 1981; Johansson et al., 2000). Haemolymph contains also soluble effectors including phenoloxidase (PO) and antimicrobial peptides. Defence mechanisms, which include wound repair, coagulation, nodule formation, encapsulation, phagocytosis and cytotoxicity (Cheng, 1981), could be impaired by hydrocarbons (Coles et al., 1994; McVeigh et al., 2006; Wootton et al., 2003). Some authors described phagocytosis and other haemocyte parameters including non-specific esterase activity and lysosomal presence, as suitable biomarkers of pollution in different bivalve species (Auffret, 2005; Gagnaire et al., 2006a). PO was reported as been modified by xenobiotics in the Pacific oyster, C. gigas (Bouilly et al., 2006; Gagnaire et al., 2004).

Field concentrations of different PAHs were first determined in the Marennes-Oleron Basin (Charente-Maritime, France), where oyster production is an important economic activity. In vitro effects of selected hydrocarbons at high and field concentrations were then monitored on haemocytes of Pacific oysters, C. gigas. Sixteen PAHs were selected from the United States Environmental Protection Agency (US-EPA) list and two oils (heavy fuel oil (HFO) and diesel oil) were also tested. Cell mortality, phagocytosis, percentage of non-specific esterase positive cells and lysosome presence were monitored using flow cytometry. Phenoloxidase (PO) activity was studied in the acellular fraction by spectrophotometry.

\section{Material and methods}

\subsection{Concentrations of PAHs in seawater samples}

Three samples were collected in October 2005 from each site (Fig. 1). The harbour area corresponded to an oyster-farming harbour. One litre of subsurface seawater was collected at a depth of $3 \mathrm{~m}$ with polyethylene Nyskin's bottles and directly transferred to Duran glass bottles (Bioblock) which were heated to $500{ }^{\circ} \mathrm{C}$ before use. Samples were kept at $4{ }^{\circ} \mathrm{C}$ in the dark until analysis. Analyses of the aromatic compounds were carried out two days later.

Samples were extracted with $30 \mathrm{~mL}$ of dichloromethane pestipur quality (SDS). After separation of the organic and aqueous phases, water was extracted two additional times by the same volume of dichloromethane $(2 \times 30 \mathrm{~mL})$. The organic extracts were purified and treated using gas chromatography coupled with mass spectrometry (GC-MS, Hewlett Packard HP5890 coupled with an HP5972 mass selective detector) following procedures previously described (Douglas et al., 1992). 


\subsection{Oysters}

Two hundred Pacific oysters, Crassostrea gigas, 8-10 cm in shell length, were purchased from a shellfish farm (La Tremblade, Charente-Maritimes, France) in October 2005. Oysters were maintained, at Ifremer's laboratory (La Tremblade, France), for one month in tanks receiving a constant flow of external seawater (temperature $15.3-16{ }^{\circ} \mathrm{C}, \mathrm{pH} 7.6$, salinity $33.9-34.5 \%$, free of nitrate and nitrite). 


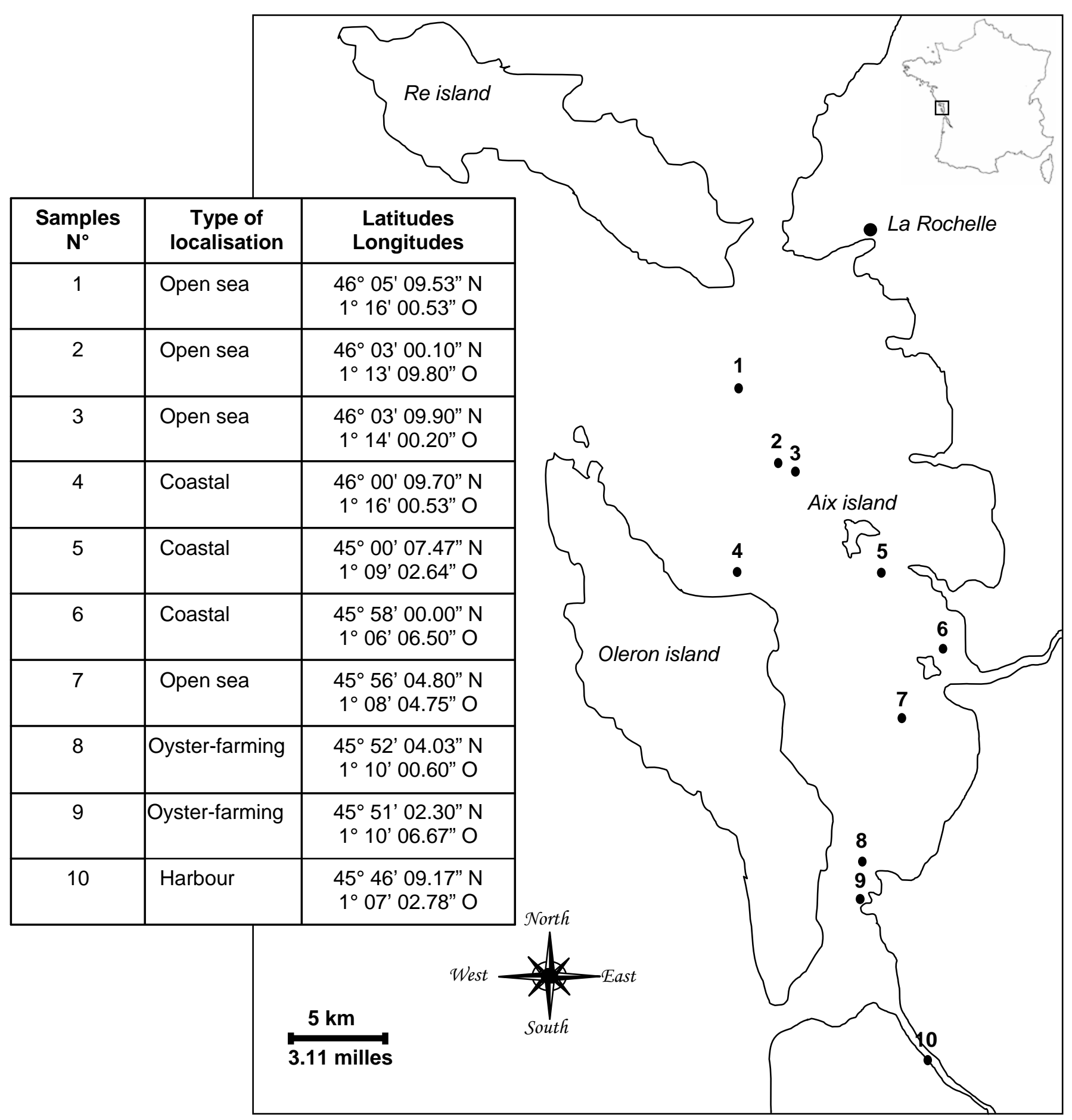

Fig. 1: Locations of the sampling sites in the Bay of Marennes-Oleron, background card issue from the National Geographic Institute.

\begin{tabular}{|c|c|c|c|}
\hline Name of 16 PAHs US-EPA & $\begin{array}{c}\text { Molecular weight } \\
\left(\mathrm{g} \cdot \mathrm{mol}^{-1}\right)\end{array}$ & $\begin{array}{c}\text { Concentration }\left(\mu \mathrm{g} \cdot \mathrm{g}^{-1} \pm\right. \\
\mathrm{SE}) \\
\text { in HFO }\end{array}$ & $\begin{array}{c}\text { Concentration }\left(\mu \mathrm{g} \cdot \mathrm{g}^{-1} \pm\right. \\
\mathrm{SE})\end{array}$ \\
in diesel oil
\end{tabular}




\begin{tabular}{|l|c|c|c|}
\hline Naphthalene & 128,2 & $686.5 \pm 51.5$ & $1244.2 \pm 49.9$ \\
Acenaphthylene & 152,2 & $51.1 \pm 1.8$ & $72.4 \pm 3.5$ \\
Acenaphthene & 154,2 & $272.5 \pm 8.4$ & $90.7 \pm 3.6$ \\
Fluorene & 166,2 & $396.4 \pm 11.5$ & $187.2 \pm 8.9$ \\
Phenanthrene & 178,2 & $1936.9 \pm 67.3$ & $186.3 \pm 15.2$ \\
Anthracene & 178,2 & $213.6 \pm 16.6$ & $13.7 \pm 0.8$ \\
Fluoranthene & 202,3 & $125.2 \pm 8.6$ & $17.9 \pm 1.1$ \\
Pyrene & 202,3 & $516.2 \pm 33.1$ & $56.9 \pm 3.5$ \\
Benz[a]anthracene & 228,3 & $213.4 \pm 8.0$ & $1.4 \pm 0.1$ \\
Chrysene & 228,3 & $464.9 \pm 8.2$ & $6.5 \pm 0.5$ \\
Benzo[b+k]fluoranthene & 252,3 & $81.4 \pm 6.8$ & n.d. \\
Benzo[a]pyrene & 252,3 & $167.9 \pm 4.5$ & n.d. \\
Benzo[g,h,i]perylene & 276,3 & $48.1 \pm 2.1$ & n.d. \\
Indeno $[1,2,3-c, d]$ pyrene & 276,3 & $16.6 \pm 2.0$ & n.d. \\
Dibenz[a, $h$ ]anthracene & 278,4 & $27.6 \pm 3.3$ & n.d. \\
\hline
\end{tabular}

Table 1: Concentration of 16 priority PAHs of the US-EPA list in heavy fuel oil (HFO) and diesel oil. PAH detection was performed by gas chromatography coupled with mass spectroscopy (GC-MS). The results are expressed in $\mu \mathrm{g} \cdot \mathrm{g}^{-1}(\mathrm{n}=3$, mean \pm standard error; $n . d .=$ not detected).

\subsection{Haemolymph collection}

After breaching the oyster shell using pincers, approximately $2 \mathrm{~mL}$ of haemolymph were withdrawn from the posterior adductor muscle sinus using a $2 \mathrm{~mL}$ syringe equipped with a needle $(0.6 \times 25 \mathrm{~mm})$. For each oyster, the haemolymph was filtered through a $60 \mu \mathrm{m}$ mesh to eliminate debris and kept on ice until it was processed to reduce haemocyte aggregation (Auffret and Oubella, 1997).

For pre-experiments, which compared individual and pooled haemolymphs, $150 \mu \mathrm{L}$ of ten haemolymph samples were pooled together. The remaining ten haemolymphs were kept for individual analysis. All samples were adjusted at $10^{6}$ cells. $\mathrm{mL}^{-1}$ with artificial seawater (for $1 \mathrm{~L}: 234 \mathrm{~g}$ $\mathrm{NaCl}, 15 \mathrm{~g} \mathrm{KCl}, 12 \mathrm{~g} \mathrm{MgSO}_{4} 4 \mathrm{H}_{2} \mathrm{O}, 1.5 \mathrm{~g} \mathrm{CaCl}_{2} 2 \mathrm{H}_{2} \mathrm{O}, 1.5 \mathrm{~g} \mathrm{CaCl}_{2}$ anhydrous; used at 1/10 dilution; all products come from Sigma) (Gagnaire et al., 2006a).

For the in vitro exposure, the haemolymph of 45 oysters was pooled, kept on ice to prevent haemocyte aggregation (Auffret and Oubella, 1997) and adjusted at $10^{6}$ cells. $\mathrm{mL}^{-1}$ with artificial seawater (Gagnaire et al., 2006a).

Three pool samples were making for pre-experiments and for the in vitro exposure.

\subsection{Experimental protocol}

2.4.1. In vitro exposure protocol

For pre-experiments the difference between pool and individual contaminated samples was researched. Based on previously published results (Gagnaire et al., 2006a), two xenobiotics were selected. The effects of fluorene and pyrene were tested on cell mortality, phagocytosis percentage, percentage of non-specific esterase positive cells and lysosome presence. Both PAH were tested at $10^{-9} \mathrm{mg} \mathrm{mL}^{-1}$ at $15^{\circ} \mathrm{C}$ during $24 \mathrm{~h}$. 
For in vitro exposure experiments, impact of chemicals on haemocyte parameters was monitored using 18 xenobiotics selected for their immunotoxic potential: 16 PAHs of the United States Environmental Protection Agency list (US-EPA) (WHO, 1997), and two oils (heavy fuel oil (HFO) and diesel oil). Concentrations of PAHs were determined in heavy fuel oil (HFO) and diesel oil (Table 1). High $\left(10^{-3}\right.$ and $\left.10^{-5} \mathrm{mg} \cdot \mathrm{mL}^{-1}\right)$ and field $\left(10^{-7}\right.$ and $\left.10^{-9} \mathrm{mg}^{-1} \mathrm{~mL}^{-1}\right)$ concentrations were tested for each $\mathrm{PAH}$. The two oils were tested in their pure form and diluted to 1/1 000 and 1/10 000 in artificial seawater after a three-day contact period without mixing at ambient temperature $\left(20^{\circ} \mathrm{C}\right)$ as previously described (Anderson et al., 1974).

Pollutants (PAHs and oils) were added individually at $5 \mu \mathrm{L}$ per $\mathrm{mL}$ of haemocyte suspension. Before addition, PAHs were dissolved in cyclohexane (Sigma) and the ratio cyclohexane:haemocyte suspension did not exceed $0.5 \%$ as recommended by manufacturers in order to avoid disturbance of cell parameters. In all experiments, the same volume of cyclohexane was used as solvent control and haemolymph alone was used as cell control. Samples were incubated at $15^{\circ} \mathrm{C}$ during 4 and $24 \mathrm{~h}$ as previously described by Gagnaire et al. (2006a). Experiments including controls were carried out three times.

\subsubsection{Cell analysis by flow cytometry}

Haemocyte mortality, phagocytosis percentage, percentage of non-specific esterase positive cells and lysosome presence were analysed with an EPICS XL 4 (Beckman Coulter). For each haemocyte sample, 10000 events were counted using protocols previously described (Gagnaire et al., 2006a). Analyses were carried out on whole haemocytes without distinguishing cell subpopulation and results were expressed as percentage of positive cells.

Cell mortality was measured using FL3 (red fluorescence). Propidium iodide (PI, 1.0 g. $\mathrm{L}^{-1}$, Molecular Probes) is membrane impermeant and is excluded from viable cells. Mortality was determined using $200 \mu \mathrm{L}$ of haemocyte suspension and $10 \mu \mathrm{L}$ of PI. Cell suspensions were incubated for 30 minutes at $4^{\circ} \mathrm{C}$.

The phagocytosis percentage was determined using FL1 (green fluorescence). Fluorescent microspheres $\left(2.7 \times 10^{10}\right.$ particles. $\mathrm{mL}^{-1}$, Fluorospheres ${ }^{\circledR}$ carboxylate-modified microspheres, diameter $1 \mu \mathrm{m}$, Molecular Probes) were used and the fluorescence setting was established using a suspension of fluorescent beads in distilled water. Only the events showing a fluorescence of at least three beads were considered positive for phagocytic activity. Phagocytic activity of haemocyte suspensions was analysed on $200 \mu \mathrm{L}$ of haemolymph samples and $10 \mu \mathrm{L}$ of a $1 / 10$ dilution of fluorescent beads. Cell suspensions were incubated for one hour at room temperature.

Percentage of non-specific esterase positive cells was analysed using the non-specific liposoluble substrate fluoresceine diacetate (FDA, Molecular Probes). One $\mu \mathrm{L}$ of a FDA solution (400 $\mu \mathrm{M}$ ) was added to $200 \mu \mathrm{L}$ of haemocyte suspension. Cells were incubated for 30 minutes in the dark at room temperature and then the reaction was stopped on ice (5 min).

Lysosome presence was analysed with a commercial kit (LysoTracker ${ }^{\circledR}$ Green DND-26, 1mM in DMSO, Molecular Probes) which consists of a fluorophore linked to a weak base that is partially protonated at neutral $\mathrm{pH}$. The LysoTracker ${ }^{\circledR}$ is freely permeant to cell membranes and typically concentrated in lysosomes. One $\mu \mathrm{L}$ of a LysoTracker marker was added to $200 \mu \mathrm{L}$ of haemocyte suspension. Samples were incubated for two hours in the dark at room temperature and then the reaction was stopped on ice (5 $\mathrm{min})$.

\subsubsection{PO activity analysis}

Haemolymph samples were centrifuged $\left(260 \mathrm{~g}, 10 \mathrm{~min}, 4^{\circ} \mathrm{C}\right)$ and supernatants recovered. Detection of phenoloxidase (PO) activity in acellular fraction samples was carried out by measurement of L-3,4-dihydroxyphenylalanine (L-Dopa, Sigma) transformation in dopachromes as previously described by Gagnaire et al. (2004). Samples were distributed in 96-well microplates (Nunc, France). PO modulators were used to confirm the specificity of the detection. The purified trypsin TPCK ( $N$-Tosyl-L-phenylalanine chloromethyl ketone, $1 \mathrm{~g} \cdot \mathrm{L}^{-1}$, Sigma) was used as an activator and the $\beta$-2-mercaptoethanol (10 mM, Sigma) was used as an inhibitor. To determine the PO activity, $80 \mu \mathrm{L}$ of cacodylate buffer (CAC buffer: sodium cacodylate $(10 \mathrm{mM})$, trisodium citrate $(100 \mathrm{mM}), \mathrm{NaCl}$ 
(0.45 M), $\left.\mathrm{CaCl}_{2}(10 \mathrm{mM}), \mathrm{MgCl}_{2}(26 \mathrm{mM}), \mathrm{pH} 7.0\right), 20 \mu \mathrm{L}$ of L-Dopa (3 mg. $\mathrm{mL}^{-1}$ ) and $20 \mu \mathrm{L}$ of samples were added in each well. To measure the PO activity modulation, $60 \mu \mathrm{L}$ of CAC buffer, $20 \mu \mathrm{L}$ of PO modulators, $20 \mu \mathrm{L}$ of L-Dopa and $20 \mu \mathrm{L}$ of samples were added to each well. Control $(120 \mu \mathrm{L}$ of CAC buffer) and negative control (100 $\mu \mathrm{L}$ of CAC buffer, $20 \mu \mathrm{L}$ of L-Dopa) wells were used to determine respectively the purity of the buffer and the autooxidation capacities of L-Dopa. Each sample was tested in nine replicates and absorbance was measured at $490 \mathrm{~nm}$ after a $21 \mathrm{~h}$ incubation period at room temperature.

\subsection{Statistical analysis}

Statistical tests were carried out using XLStat Pro 7.5.3. A Kruskal-Wallis test, for non normal values, was used to analyse pollutant effects and a Mann-Whitney test was applied to compare the protocol effects. In the case of the rejection of $\mathrm{H}_{0}$, a Dunn test for non normal values was used. $\mathrm{P}$ values lower than 0.05 were used to identify significant differences.

\section{Results}

\subsection{PAH concentrations in the Marennes-Oleron Basin (Charente-Maritime, France)}

The concentrations of $16 \mathrm{PAHs}$ in seawater samples are given in Table 2. The values ranged from 0 to $53.8 \mathrm{ng} \cdot \mathrm{L}^{-1}$ with $\mathrm{a}$ total concentration of $70.5 \pm 10.8 \mathrm{ng} \cdot \mathrm{L}^{-1}$. Indeno[1,2,3-c, $\left.d\right]$ pyrene, benzo[b]fluoranthene and benzo[g,h,i]perylene were not detected at all sampling sites. Acenaphthene, chrysene, fluoranthene, fluorene, naphthalene and phenanthrene were detected at all sampling sites. Three types of sampling sites, "open sea", "coastal and harbour" and "oyster-farming", were differentiated in terms of total amounts of seawater PAH concentrations. The "open sea" sites showed the lowest concentrations with values ranging from $12.3 \pm 1.4 \mathrm{ng} \cdot \mathrm{L}^{-1}$ for naphthalene to $0.1 \mathrm{ng} \cdot \mathrm{L}^{-1}$ for chrysene and with a total concentration of $39.0 \pm 3.7 \mathrm{ng} \cdot \mathrm{L}^{-1}$. Twelve PAHs among the 16 analysed were detected. The "coastal and harbour" sites showed concentrations ranging from $33.8 \pm 3.4 \mathrm{ng} . \mathrm{L}^{-1}$ for acenaphthene to $0.8 \pm 0.5 \mathrm{ng} \cdot \mathrm{L}^{-1}$ for anthracene and with a total concentration of $75.9 \pm 3.3 \mathrm{ng} \cdot \mathrm{L}^{-1}$. Eight PAHs among the 16 analysed were detected. The highest total concentration (123.1 $\left.\pm 18.1 \mathrm{ng} \cdot \mathrm{L}^{-1}\right)$ was observed in the "oyster-farming" sites with values ranging from $48.7 \pm 5.2 \mathrm{ng} \cdot \mathrm{L}^{-1}$ for naphthalene to $0.2 \pm 0.2 \mathrm{ng} \cdot \mathrm{L}^{-1}$ for acenaphthylene. Nine PAHs among the 16 analysed were detected. 

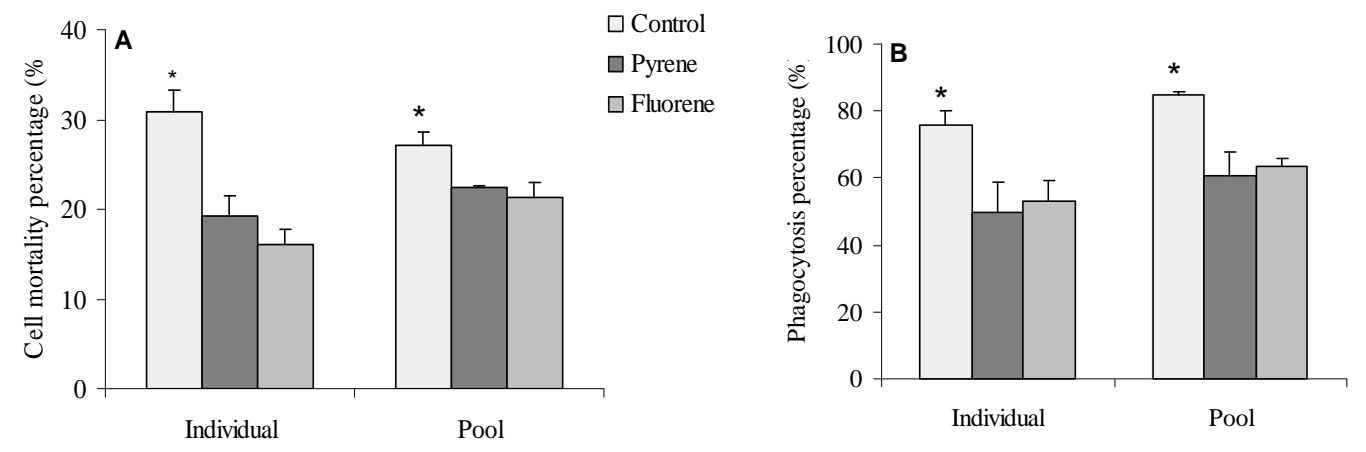

$\square$ Control

$\square$ Pyrene

$\square$ Fluorene
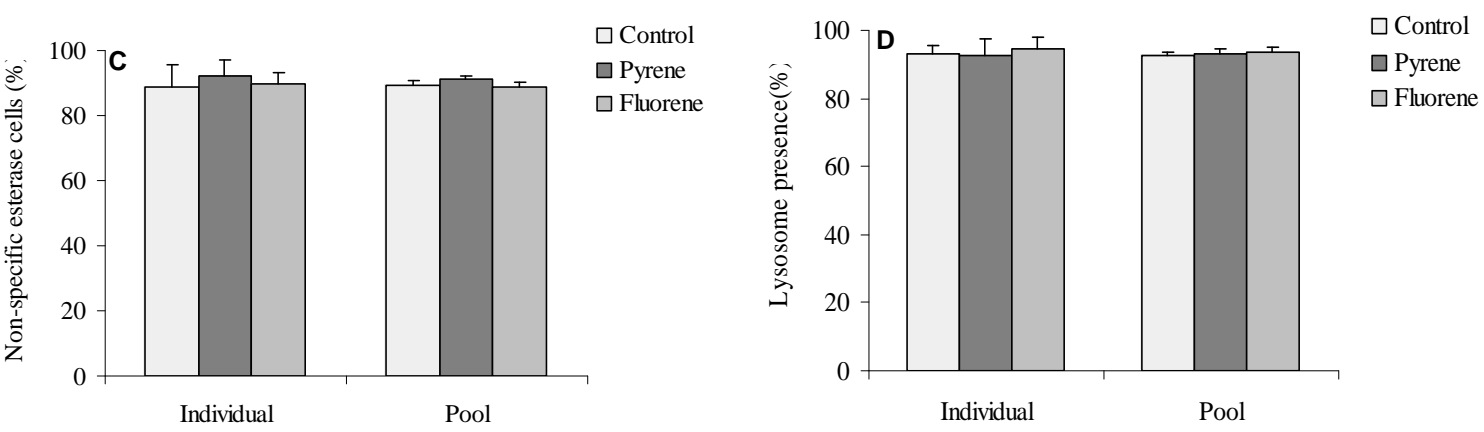

Fig. 2: Cellular mortality percentage (A), phagocytic percentage (B), percentage of non-specific positive esterase cells (C) and lysosome presence (D) of haemocytes measured by flow cytometry following an in vitro exposure of $24 \mathrm{~h}$ at $15^{\circ} \mathrm{C}$ to pyrene, fluorene at $10^{-9} \mathrm{mg}^{\mathrm{mL}} \mathrm{m}^{-1}$ for both samples (individual and pooled samples). Values are the mean of three replicates. The bars represent the standard error. ${ }^{*}=$ statistical difference for $p \leq 0.05$. 


\begin{tabular}{|c|c|c|c|c|c|c|c|c|c|c|c|c|c|c|}
\hline \multirow[b]{2}{*}{16 PAHs US-EPA } & \multicolumn{5}{|c|}{ Open sea } & \multicolumn{5}{|c|}{ Coastal and harbour } & \multicolumn{3}{|c|}{ Oyster-farming } & \multirow{2}{*}{$\begin{array}{l}\text { Mean } \\
( \pm \text { SE })\end{array}$} \\
\hline & 1 & 2 & 3 & 7 & Mean & 4 & 5 & 6 & 10 & Mean & 8 & 9 & Mean & \\
\hline Naphthalene & $15.0 \pm 0.6$ & $14.4 \pm 0.9$ & $9.2 \pm 0.6$ & $10.4 \pm 0.3$ & $12.3 \pm 1.4$ & $25.8 \pm 0.2$ & $25.8 \pm 0.4$ & $25.7 \pm 0.5$ & $18.5 \pm 0.5$ & $24.0 \pm 1.8$ & $53.8 \pm 0.2$ & $43.5 \pm 0.5$ & $48.7 \pm 5.2$ & $25.2 \pm 4.6$ \\
\hline Acenaphthylene & $2.6 \pm 0.1$ & $2.6 \pm 0.0$ & $2.4 \pm 0.0$ & $2.7 \pm 0.1$ & $2.6 \pm 0.1$ & n.d. & n.d. & n.d. & n.d. & n.d. & n.d. & $0.4 \pm 0.0$ & $0.2 \pm 0.2$ & $0.9 \pm 0.4$ \\
\hline Acenaphthene & $8.0 \pm 0.1$ & $8.0 \pm 0.0$ & $8.2 \pm 0.2$ & $8.1 \pm 0.1$ & $8.1 \pm 0.0$ & $33.6 \pm 0.5$ & $29.8 \pm 0.3$ & $28.3 \pm 0.2$ & $43.4 \pm 0.5$ & $33.8 \pm 3.4$ & $43.5 \pm 0.3$ & $33.6 \pm 0.2$ & $38.6 \pm 5.0$ & $26.3 \pm 4.7$ \\
\hline Fluorene & $3.4 \pm 0.1$ & $4.9 \pm 0.1$ & $3.3 \pm 0.1$ & $4.9 \pm 0.2$ & $4.1 \pm 0.4$ & $1.8 \pm 0.1$ & $2.1 \pm 0.0$ & $2.0 \pm 0.0$ & $1.5 \pm 0.0$ & $1.9 \pm 0.1$ & $1.2 \pm 0.0$ & $1.4 \pm 0.0$ & $1.3 \pm 0.1$ & $2.6 \pm 0.4$ \\
\hline Phenanthrene & $1.4 \pm 0.1$ & $2.0 \pm 0.1$ & $0.4 \pm 0.0$ & $1.5 \pm 0.1$ & $1.3 \pm 0.3$ & $8.4 \pm 0.1$ & $13.1 \pm 0.2$ & $5.1 \pm 0.1$ & $6.3 \pm 0.2$ & $8.2 \pm 1.8$ & $6.0 \pm 0.1$ & $13.2 \pm 0.2$ & $9.6 \pm 3.6$ & $6.2 \pm 1.5$ \\
\hline Anthracene & n.d. & n.d. & n.d. & n.d. & n.d. & $1.3 \pm 0.0$ & n.d. & n.d. & $1.8 \pm 0.0$ & $0.8 \pm 0.5$ & n.d. & $2.1 \pm 0.0$ & $1.1 \pm 1.1$ & $0.6 \pm 0.3$ \\
\hline Fluoranthene & $3.6 \pm 0.1$ & $3.5 \pm 0.0$ & $3.3 \pm 0.0$ & $3.5 \pm 0.1$ & $3.5 \pm 0.1$ & $2.8 \pm 0.0$ & $0.9 \pm 0.0$ & $0.8 \pm 0.1$ & $1.0 \pm 0.0$ & $1.4 \pm 0.5$ & $1.2 \pm 0.0$ & $2.4 \pm 0.0$ & $1.8 \pm 0.6$ & $2.2 \pm 0.4$ \\
\hline Pyrene & $3.1 \pm 0.1$ & $3.0 \pm 0.1$ & $4.0 \pm 0.1$ & $2.8 \pm 0.1$ & $3.2 \pm 0.3$ & n.d. & $2.7 \pm 0.0$ & $2.0 \pm 0.0$ & $3.9 \pm 0.1$ & $2.2 \pm 0.8$ & $2.6 \pm 0.0$ & $3.7 \pm 0.0$ & $3.2 \pm 0.5$ & $2.7 \pm 0.4$ \\
\hline Benz[a]anthracene & $0.4 \pm 0.0$ & $0.3 \pm 0.0$ & $0.5 \pm 0.0$ & $0.4 \pm 0.0$ & $0.4 \pm 0.0$ & n.d. & n.d. & n.d. & n.d. & n.d. & n.d. & n.d. & n.d. & $0.1 \pm 0.1$ \\
\hline Chrysene & $0.1 \pm 0.0$ & $0.1 \pm 0.0$ & $0.2 \pm 0.0$ & $0.1 \pm 0.0$ & $0.1 \pm 0.0$ & $2.0 \pm 0.0$ & $8.0 \pm 0.1$ & $3.0 \pm 0.1$ & $1.9 \pm 0.0$ & $3.7 \pm 1.4$ & $32.8 \pm 0.3$ & $4.7 \pm 0.1$ & $\begin{array}{c}18.8 \pm \\
14.1\end{array}$ & $5.9 \pm 3.2$ \\
\hline Benzo $[b]$ fluoranthene & n.d. & n.d. & n.d. & n.d. & n.d. & n.d. & n.d. & n.d. & n.d. & n.d. & n.d. & n.d. & n.d. & n.d. \\
\hline Benzo $[k]$ fluoranthene & $0.8 \pm 0.0$ & $0.7 \pm 0.0$ & $0.8 \pm 0.0$ & $0.8 \pm 0.0$ & $0.8 \pm 0.0$ & n.d. & n.d. & n.d. & n.d. & n.d. & n.d. & n.d. & n.d. & $0.3 \pm 0.1$ \\
\hline Benzo[a]pyrene & $1.5 \pm 0.0$ & $1.4 \pm 0.0$ & $1.4 \pm 0.0$ & $1.4 \pm 0.0$ & $1.4 \pm 0.0$ & n.d. & n.d. & n.d. & n.d. & n.d. & n.d. & n.d. & n.d. & $0.5 \pm 0.2$ \\
\hline Benzo[ $[g, h, i]$ perylene & n.d. & n.d. & n.d. & n.d. & n.d. & n.d. & n.d. & n.d. & n.d. & n.d. & n.d. & n.d. & n.d. & n.d. \\
\hline $\begin{array}{l}\text { Indeno } \begin{array}{l}{[1,2,3-c, d]} \\
\text { pyrene }\end{array} \\
\text { pyren }\end{array}$ & n.d. & n.d. & n.d. & n.d. & n.d. & n.d. & n.d. & n.d. & n.d. & n.d. & n.d. & n.d. & n.d. & n.d. \\
\hline Dibenz[a,h]anthracene & $2.3 \pm 0.0$ & n.d. & n.d. & $2.4 \pm 0.0$ & $1.2 \pm 0.7$ & n.d. & n.d. & n.d. & n.d. & n.d. & n.d. & n.d. & n.d. & $0.3 \pm 0.3$ \\
\hline Mean ( \pm SE) & $\begin{array}{c}42.2 \\
( \pm 5.2)\end{array}$ & $\begin{array}{c}40.9 \\
( \pm 2.6)\end{array}$ & $\begin{array}{c}33.7 \\
( \pm 0.9)\end{array}$ & $\begin{array}{c}39.0 \\
( \pm 0.4)\end{array}$ & $\begin{array}{c}39.0 \\
( \pm 3.7)\end{array}$ & $\begin{array}{c}75.7 \\
( \pm 2.9)\end{array}$ & $\begin{array}{c}82.4 \\
( \pm 3.4)\end{array}$ & $\begin{array}{c}66.9 \\
( \pm 2.6)\end{array}$ & $\begin{array}{c}78.4 \\
( \pm 3.2)\end{array}$ & $\begin{array}{c}75.9 \\
( \pm 3.3)\end{array}$ & $\begin{array}{l}141.1 \\
( \pm 6.1)\end{array}$ & $\begin{array}{l}105.0 \\
( \pm 5.8)\end{array}$ & $\begin{array}{c}123.1 \\
( \pm 18.1)\end{array}$ & $\begin{array}{c}70.5 \\
( \pm 10.8)\end{array}$ \\
\hline
\end{tabular}

Table 2: Concentration of 16 priority PAHs of the US-EPA list in seawater samples as function of sample localisations. PAH detection was performed by gas chromatography coupled with mass spectroscopy (GC-MS). The results are expressed in ng. $\mathrm{L}^{-1}(\mathrm{n}=3$, mean \pm standard error; $\mathrm{n} \cdot \mathrm{d}$. $=$ not detected which corresponded to a detection limit of $\left.0.1 \mathrm{ng} \cdot \mathrm{L}^{-1}\right)$. With no statistical difference at $\mathrm{p} \leq 0.05$ between each localisation type. 


\subsection{Pre-experiments: comparing individual and pooled haemocytes after incubation with pyrene and fluorene}

Similar results were obtained between cell (haemolymph alone) and solvent controls (haemolymph plus cyclohexane) for each parameter studied (data not shown).

Cell mortality was not significantly different between individual $(19.3 \pm 2.2 \%, 16.0 \pm 1.7 \%$ and $30.9 \pm 2.3 \%$ for pyrene, fluorene and control, respectively) and pooled haemocytes (22.5 \pm 0.1 $\%, 21.3 \pm 1.6 \%$ and $27.1 \pm 1.4 \%$ for pyrene, fluorene and control, respectively (Fig. 2). Pyrene and fluorene at $10^{-9} \mathrm{mg}^{-1} \mathrm{~mL}^{-1}$ induced a significant decrease in haemocyte mortality for both sample types. Phagocytosis percentages were similar for individual (49.8 $\pm 9.1 \%, 52.9 \pm 6.1 \%$ and $76.1 \pm 4.0 \%$ for pyrene, fluorene and control, respectively) and pooled haemocytes $(60.7 \pm 6.9 \%, 63.4 \pm 2.6 \%$ and $85.0 \pm 0.6 \%$ for pyrene, fluorene and control, respectively). An equal decrease in phagocytosis percentage was shown with pyrene and fluorene at $10^{-9} \mathrm{mg} \cdot \mathrm{mL}^{-1}$ compared to control samples.

Percentages of non-specific esterase positive cells were similar for individual $(92.4 \pm 4.7 \%, 89.8 \pm$ $3.6 \%$ and $88.9 \pm 6.5 \%$ for pyrene, fluorene and control, respectively) and pooled haemocytes (91.0 \pm $1.2 \%, 88.9 \pm 1.6 \%$ and $89.2 \pm 1.7 \%$ for pyrene, fluorene and control, respectively). Percentages of cells presenting lysosomes were similar for individual $(92.4 \pm 5.3 \%, 94.8 \pm 3.1 \%$ and $89.9 \pm 2.3 \%$ for pyrene, fluorene and control, respectively) and pooled haemocytes $(93.2 \pm 1.2 \%, 93.6 \pm 1.6 \%$ and $92.4 \pm 1.2 \%$ for pyrene, fluorene and control, respectively). No significant difference in percentages of non-specific esterase positive cells and lysosome presence was observed in the presence of pyrene and fluorene compared to control samples.

\subsection{In vitro exposure (Table 3)}

Compared to control samples $(28.3 \pm 3.5 \%)$, fluorene $(21.0 \pm 2.7 \%)$, pyrene $(20.7 \pm 2.3 \%)$, anthracene $(23.6 \pm 1.7 \%)$, phenanthrene $(23.0 \pm 2.7 \%)$, chrysene $(23.0 \pm 2.5 \%)$, indeno[1,2,3$c$, c]pyrene $(20.1 \pm 3.1 \%)$ and HFO $(21.8 \pm 1.2 \%)$ significantly decreased haemocyte mortality after a $24 \mathrm{~h}$ incubation. Phagocytosis activity was decreased by fluorene $(28.0 \pm 2.0 \%)$, pyrene $(27.6 \pm 2.6$

$\%)$ and pure HFO (33.5 $\pm 9.3 \%)$ after a $24 \mathrm{~h}$ 


\begin{tabular}{|c|c|c|c|c|c|}
\hline 18 pollutants used & $\begin{array}{c}\text { Cell mortality } \\
\text { (\%) }\end{array}$ & $\begin{array}{c}\text { Phagocytosis } \\
\text { (\%) }\end{array}$ & $\begin{array}{c}\text { Non-specific esterases } \\
\text { cells } \\
(\%)\end{array}$ & $\begin{array}{l}\text { Lysosome } \\
\text { presence } \\
(\%)\end{array}$ & $\begin{array}{c}\text { PO activity } \\
\left(\mathrm{A}_{490 \mathrm{~nm}}\right)\end{array}$ \\
\hline
\end{tabular}

Naphthalene EC $\left.{ }^{* *}, 24 \mathrm{~h}\right)$

Acenaphthylene

Acenaphthene

Fluorene

Phenanthrene

Anthracene

Fluoranthene

Pyrene

Benz[a]anthracene

Chrysene

Benzo[b]fluoranthene

Benzo[k]fluoranthene

Benzo[a]pyrene

Benzo[g,h,I]perylene

Indeno[1,2,3-c, $d]$ pyrene

Dibenz[a, $h]$ anthracene

\section{HFO}

Diesel oil $\boldsymbol{\nabla} E C\left(^{*}, 24 \mathrm{~h}\right) \quad \boldsymbol{\nabla} E C\left(^{*}, 24 \mathrm{~h}\right)$

$\nabla$ EC $\left({ }^{*}, 24 h\right)$

$\nabla$ EC $\left({ }^{*}, 24 h\right)$

$\boldsymbol{\nabla} E C\left({ }^{*}, 24 h\right) \quad \nabla$ EC $\left({ }^{*}, 24 h\right)$

$\boldsymbol{\nabla} E C\left({ }^{*}, 24 h\right)$

$\triangle 10^{-7}, 10^{-9} \mathrm{~g} \cdot \mathrm{L}^{-1}\left({ }^{*}, 24 \mathrm{~h}\right)$

Table 3: Cellular mortality, phagocytosis, non-specific esterase positive cells percentages and lysosome presence of oysters measured by flow cytometry and phenoloxidase (PO) activity performed by spectrophotometry following an in vitro exposure of 4 and $24 \mathrm{~h}$ at $15^{\circ} \mathrm{C}$ to 18 hydrocarbons at $10^{-3}, 10^{-5}, 10^{-7}$ and $10^{-9} \mathrm{mg} \cdot \mathrm{mL}^{-1}$. Values are means of three replicates of 45 oysters ( \pm standard error). ${ }^{*}=$ statistical difference for $p \leq 0.05$ and ${ }^{*}$ for $p \leq 0.01 ; \triangle=$ significant increase; $\mathbf{\nabla}$ = significant decrease; $\mathrm{EC}=$ each concentration. 
incubation compared to control samples $(51.7 \pm 12.0 \%)$. On the contrary, percentage of non-specific esterase positive cells $(93.2 \pm 0.4 \%$ and $89.1 \pm 0.3 \%$ for naphthalene and control, respectively) and lysosome presence $(90.9 \pm 2.3 \%$ and $88.1 \pm 3.0 \%$ for dibenz[a, $h]$ anthracene and control, respectively) were increased by naphthalene and dibenz[a, $h]$ anthracene.

Phenoloxidase activity was increased by purified trypsin TPCK and inhibited by $\beta$-2-mercaptoethanol (data not shown). Phenoloxidase activity was significantly increased with benzo[b]fluoranthene at $10^{-7}$ $(0.65 \pm 0.07)$ and $10^{-9} \mathrm{mg} \cdot \mathrm{mL}^{-1}(0.63 \pm 0.08)$ after a $24 \mathrm{~h}$ incubation period compared to control samples $(0.47 \pm 0.10)$.

\section{Discussion}

The aim of the present work was to determine the in vitro effects of high and field concentrations of hydrocarbons on haemocyte parameters of Pacific oysters, Crassostrea gigas. The tested concentrations of hydrocarbons were determined based on the literature and experimental values (determining PAH concentrations in seawater in the Marennes-Oleron Basin). The high concentrations tested in the present study $\left(10^{-3}\right.$ and $\left.10^{-5} \mathrm{mg} \mathrm{mL}^{-1}\right)$ could be compared to those observed after an oil spill. After the Prestige oil spill total aromatic hydrocarbons were detected at an average concentration of $3.10^{-5} \mathrm{mg} \cdot \mathrm{mL}^{-1}$ on the Northern Spanish coast (Gonzalez et al., 2006). The concentrations detected after the Prestige oil spill were in a lower range than those quoted in other accidentally polluted areas. Values up to $10^{-5} \mathrm{mg} \cdot \mathrm{mL}^{-1}$ were reported in the coastal waters of Brittany after the Amoco Cadiz oil spill (Marchand, 1980). For field concentrations $\left(10^{-7}\right.$ and $\left.10^{-9} \mathrm{mg}_{\mathrm{mL}}{ }^{-1}\right)$, information is available for rivers, including German rivers, Dutch rivers, the Yellow River in China (WHO, 1997) and the Thames in Great Britain (Acheson et al., 1976). Field concentrations of PAHs around $10^{-9} \mathrm{mg}^{-1} \mathrm{~mL}^{-1}$ were reported in the marine environment (Hellou et al., 2005; WHO, 1997). In the Marennes-Oleron Basin, no information on concentrations of hydrocarbons was available. In this study, PAH concentrations ranged from $10^{-7}$ and $10^{-9} \mathrm{mg}_{\mathrm{mL}} \mathrm{m}^{-1}$. In concordance with results obtained in seawater on the German coast (WHO, 1997), the composition and the concentration of PAHs in the seawater of the MarennesOleron Basin depend of the sampling sites. Our results showed that more PAHs were detected in "open sea" sites compared to "oyster-farming" and "coastal and harbour" sites. Nevertheless, lower total PAH concentration was observed in the open sea. In all sites, no detectable concentration of indeno[1,2,3-c, $d]$ pyrene, benzo[b]fluoranthene and benzo[g,h,i]perylene was found. The absence of detection in seawater may be explained by their high molecular weight which makes them less soluble and increases their affinity with particles (Meador et al., 1995). Thus, for toxicology studies, field seawater concentrations of soluble PAHs ranged from $10^{-7}$ and $10^{-9} \mathrm{mg} \cdot \mathrm{mL}^{-1}$, without emulsion or microlayers, seems to be acceptable.

Studies on Pacific oyster, C. gigas, haemocytes have used either individual (Auffret and Oubella, 1997; Duchemin et al., 2007; Jeong and Cho, 2005) or pooled samples (Aton et al., 2006; Gagnaire et al., 2006b; Luna-González et al., 2003). The use of individual samples allows few successive tests in similar conditions and with the same specimens but with a greater range of variation (Auffret and Oubella, 1997). On the contrary, the use of pooled samples provided a sufficient quantity of cells to carry out multiple analyses with the same group of animals and minimize effects related to inter-individual variations (Gagnaire et al., 2004). Results show that values for haemocyte parameters assessed using a pool of ten oyster haemolymphs were similar to the mean of ten individual values for both pollutants. For each immunotoxicity studies, pooled samples may be used to test a large number of pollutants and/or of cell parameters. Concerning difference between pool and individual contaminated samples for PO activity, previous results shown that no significant difference between both sample types was observed (Thomas-Guyon et al., personal communication).

Among the 16 pure hydrocarbons and the two oils tested, ten chemicals (nine pure hydrocarbons plus $\mathrm{HFO}$ ) were able to modify at least one haemocyte parameter after a $24 \mathrm{~h}$ incubation period. A decrease in cell mortality was reported for four PAHs (anthracene, chrysene, indeno[1,2,3-c, d] pyrene and phenanthrene) and a decrease in both cell mortality and phagocytosis percentage for three hydrocarbons (fluorene, pyrene and HFO). A phagocytosis decrease could therefore not be induced by an increase in cell destruction, but rather by a decrease in haemocyte immune capacities. Gagnaire et al. (2006a) observed that benzo[a]pyrene, phenanthrene and anthracene tested on Pacific oyster haemocytes induced a similar decrease in cell mortality after a $24 \mathrm{~h}$ incubation. The impact of hydrocarbons on haemocytes was controversial. Sami et al. (1992) and Jeong and Cho (2005) reported a decrease in the number of haemocytes in the oysters, $C$. virginica and $C$. gigas, without 
affecting cell mortality, when Coles et al. (1994) observed that fluoranthene increased the total cell number without modifying subpopulation percentages. Furthermore, Grundy et al. (1996b) demonstrated an in vitro inhibitor effect on the common mussel, Mytilus edulis, with anthracene, fluoranthene and phenanthrene. In marine environment, microorganisms, especially bacteria, play an important role in the aerobic biodegradation of PAHs essentially for phenanthrene, fluorene and anthracene (Kasai et al., 2002). Moreover, microorganisms were naturally present in haemolymph related to the open circulatory system in bivalves (Cheng, 1981). Then, the diminution of cell mortality in contaminated haemocytes compared to control haemocytes could be explain by two hypothesis: i) for high concentrations, bacteria are more impaired by hydrocarbons than haemocytes; ii) for field concentrations, it means lower level of hydrocarbons, PAHs are more accessible to bacteria as carbon and energy sources than haemocytes.

Naphthalene has a low molecular weight and a toxic potential due to its polycyclic nature. In our experimental conditions, each concentration of naphthalene increased percentage of non-specific esterase positive cells, after a $24 \mathrm{~h}$ incubation. In the opposite, decrease of percentage of non-specific esterase positive cells were shown after 4 and $24 \mathrm{~h}$ of oyster haemocyte exposure to benzo[a]pyrene, phenanthrene, anthracene and fluoranthene (Gagnaire et al., 2006a). This discrepancy could be due to the concentrations used in each study.

In this study, dibenz $[a, h]$ anthracene is associated with an increase in lysosome presence after in vitro contact at high and field concentrations. Lysosomes are usually decreased by PAHs which induced destabilisation of lysosomal membranes (Gagnaire et al., 2006a; Grundy et al., 1996b; Grundy et al., 1996a; McVeigh et al., 2006). However, Braunbeck and Appelbaum (1999) also observed a proliferation of lysosomes on intestinal epithelium in Cyprinus carpio after oral contamination with an ultra-low dose of cyclodiene insecticide endosulfan. This lysosomal proliferation has to be classed as an unspecific reaction of the intestinal mucosa to stress due to xenobiotics (Braunbeck and Appelbaum, 1999). In this study, the increase in lysosomal percentage might also represent unspecific signs of stress.

The PO system is an important immune defence mechanism in invertebrates which is found in the Pacific oyster, Crassotrea gigas (Hellio et al., 2007). In this work, PO activity increased after $24 \mathrm{~h}$ of in vitro contact between haemolymph free of cells and benzo[b]fluoranthene at high concentrations. Some authors have previously described an increase in PO activity after in vivo pollutant exposures, e.g. fluoranthene in mussels (Coles et al., 1994), tributyltin and copper in tunicates (Tujula et al., 2001) and cadmium in Pacific oysters (Bouilly et al., 2006). On the contrary, some pollutants decreased PO activity in vitro such as mercury in the Pacific oysters (Gagnaire et al., 2004) and in vivo such as trichlorfon in prawns (Chang et al., 2006). In these in vitro experimentations, benzo[b]fluoranthene does not modulate other haemocyte parameters, thus the increase in PO activity in Pacific oysters could be due to direct action of the pollutant on this activity.

\section{Conclusions}

This work analyse the in vitro effects of 16 pure hydrocarbons and two oils on immune haemocyte capacities. Each parameter was modulated by at least one pollutant. In the case of fluorene and pyrene, which are very representative in HFO, they have effects on both cellular mortality and phagocytic activity. Moreover, the PAHs which had immune effects are more accurately represented in HFO than in diesel oil, which had no effect on immune parameters. It could be interesting to develop the synergic or antagonist effects of these potential immunomodulators and to research their effects in in vivo experimentations.

\section{Acknowledgments}

M. Girin is acknowledged for allowing the work to be conducted at Cedre in Brest (Brittany, France). This research was supported by the Ifremer research program 'MORtalités ESTivales' (France) and by the European program 'Interreg IIIB, Erocips'. Thanks to Sally Ferguson for her reading of this document and to Dominique Vilday for his help with the seawater sampling in the Marennes-Oleron Basin. 


\section{References}

Acheson, M. A., Harrison, R. M., Perry, R. and Wellings, R. A., 1976. Factors affecting the extraction and analysis of polynuclear aromatic hydrocarbons in water. Water Research 10, 207-212.

Anderson, J. W., Neff, J. M., Cox, B. A., Tatem, H. E. and Hightower, G. M., 1974. Characteristics of dispersions and water-soluble extracts of crude and refined oils and their toxicity to estuarine crustaceans and fish. Marine Biology 27, 75-88.

Aton, E., Renault, T., Gagnaire, B., Thomas-Guyon, H., Cognard, C. and Imbert, N., 2006. A flow cytometric approach to study intracellular-free $\mathrm{Ca} 2+$ in Crassostrea gigas haemocytes. Fish \& Shellfish Immunology 20, 493-502.

Auffret, M. and Oubella, R., 1997. Hemocyte aggregation in the oyster Crassostrea gigas: In vitro measurement and experimental modulation by xenobiotics. Comparative Biochemistry and Physiology Part A: Physiology 118, 705-712.

Auffret, M., 2005. Chapter 3: Bivalves as models for marine immunotoxicology, in: H. Tryphonas, M. F., B.R.Blakley, J.E.G Smits and P. Brousseau (eds), CRC Press, Boca Raton, Investigative immunotoxicology, 29-48.

Boehm, P. D., Neff, J. M. and Page, D. S., 2007. Assessment of polycyclic aromatic hydrocarbon exposure in the waters of Prince William Sound after the Exxon Valdez oil spill: 1989-2005. Marine Pollution Bulletin 54, 339-356.

Bouilly, K., Gagnaire, B., Bonnard, M., Thomas-Guyon, H., Renault, T., Miramand, P. and Lapègue, S., 2006. Effects of cadmium on aneuploidy and hemocyte parameters in the Pacific oyster, Crassostrea gigas. Aquatic Toxicology 78, 149-156.

Braunbeck, T. and Appelbaum, S., 1999. Ultrastructural alterations in the liver and intestine of carp Cyprinus carpio induced orally by ultra-low doses of endosulfan. Diseases of Aquatic Organisms 36, 183-200.

Budzinski, H., Jones, I., Bellocq, J., Piérard, C. and Garrigues, P., 1997. Evaluation of sediment contamination by polycyclic aromatic hydrocarbons in the Gironde estuary. 4th International Symposium on the Biogeochemistry of Model Estuaries, 58, 85-97.

Chang, C.C., Lee, P.-P., Liu, C. H. and Cheng, W., 2006. Trichlorfon, an organophosphorus insecticide, depresses the immune responses and resistance to Lactococcus garvieae of the giant freshwater prawn Macrobrachium rosenbergii. Fish \& Shellfish Immunology 20, 574-585.

Cheng, T. C., 1981. Bivalves, in: Ratcliffe, N. A. and Rowley, A. F., Invertebrate Blood Cells I, Academic Press, London, 233-299.

Coles, J. A., Farley, S. R. and Pipe, R. K., 1994. Effects of fluoranthene on the immunocompetence of the common marine mussel, Mytilus edulis. Aquatic Toxicology 30, 367-379.

Douglas, G. S., McCarthy, K. J., Dahlen, D. T., Seavey, J. A., Steinhauer, W. G., Prince, R. C. and Elmendorf, D. L., 1992. The use of hydrocarbon analyses for environmental assessment and remediation. Journal of Soil Contamination 1, 197-216.

Duchemin, M. B., Fournier, M. and Auffret, M., 2007. Seasonal variations of immune parameters in diploid and triploid Pacific oysters, Crassostrea gigas (Thunberg). Aquaculture 264, 73-81.

Franco, M. A., Vinas, L., Soriano, J. A., de Armas, D., Gonzalez, J. J., Beiras, R., Salas, N., Bayona, J. M. and Albaiges, J., 2006. Spatial distribution and ecotoxicity of petroleum hydrocarbons in sediments from the Galicia continental shelf (NW Spain) after the Prestige oil spill. Marine Pollution Bulletin, The Prestige Oil Spill: A Scientific Response 53, 260-271.

Gagnaire, B., Thomas-Guyon, H. and Renault, T., 2004. In vitro effects of cadmium and mercury on Pacific oyster, Crassostrea gigas (Thunberg), haemocytes. Fish \& Shellfish Immunology 16, 501-512.

Gagnaire, B., Thomas-Guyon, H., Burgeot, T. and Renault, T., 2006a. Pollutant effects on Pacific oyster, Crassostrea gigas (Thunberg), hemocytes: Screening of 23 molecules using flow cytometry. Cell Biology and Toxicology 22, 1-14.

Gagnaire, B., Frouin, H., Moreau, K., Thomas-Guyon, H. and Renault, T., 2006b. Effects of temperature and salinity on haemocyte activities of the Pacific oyster, Crassostrea gigas (Thunberg). Fish \& Shellfish Immunology 20, 536-547.

Gonzalez, J. J., Vinas, L., Franco, M. A., Fumega, J., Soriano, J. A., Grueiro, G., Muniategui, S., Lopez-Mahia, P., Prada, D. and Bayona, J. M., 2006. Spatial and temporal distribution of dissolved/dispersed aromatic hydrocarbons in seawater in the area affected by the Prestige oil spill. The Prestige Oil Spill: A Scientific Response In Marine Pollution Bulletin 53, 250-259.

Grundy, M. M., Ratcliffe, N. A. and Moore, M. N., 1996a. Immune inhibition in marine mussels by polycyclic aromatic hydrocarbons. Marine Environmental Research 42, 187-190. 
Grundy, M. M., Moore, M. N., Howell, S. M. and Ratcliffe, N. A., 1996b. Phagocytic reduction and effects on lysosomal membranes by polycyclic aromatic hydrocarbons, in haemocytes of Mytilus edulis. Aquatic Toxicology 34, 273-290.

Halldorsson, H. P., Ericson, G. and Svavarsson, J., 2004. DNA strand breakage in mussels (Mytilus edulis L.) deployed in intertidal and subtidal zone in Reykjavik harbour. Marine Environmental Research 58, 763-767.

Hellio, C., Bado-Nilles, A., Gagnaire, B., Renault, T. and Thomas-Guyon, H., 2007. Demonstration of a true phenoloxidase activity and activation of a ProPO cascade in Pacific oyster, Crassostrea gigas (Thunberg) in vitro. Fish \& Shellfish Immunology 22, 433-440.

Hellou, J., Steller, S., Leonard, J., Langille, M. A. and Tremblay, D., 2005. Partitioning of polycyclic aromatic hydrocarbons between water and particles compared to bioaccumulation in mussels: a harbour case. Marine Environmental Research 59, 101-117.

Jeong, W.G. and Cho, S.M., 2005. Effects of polynuclear aromatic hydrocarbons on hemocyte characteristics of the pacific oyster, Crassostrea gigas. Journal of Shellfish Research 24, 451-456.

Johansson, M. W., Keyser, P., Sritunyalucksana, K. and Söderhäll, K., 2000. Crustacean haemocytes and haematopoiesis. Aquaculture 191, 45-52.

Kasai, Y., Kishira, H. and Harayama, S., 2002. Bacteria belonging to the genus cycloclasticus play a primary role in the degradation of aromatic hydrocarbons released in a marine environment. Applied and Environmental Microbiology 68, 5625-5633.

Law, R. J., 1978. Determination of petroleum hydrocarbons in water, fish and sediments following the Ekofisk blow-out. Marine Pollution Bulletin 9, 321-324.

Luna-González, A., Maeda-Martínez, A. N., Vargas-Albores, F., Ascencio-Valle, F. and RoblesMungaray, M., 2003. Phenoloxidase activity in larval and juvenile homogenates and adult plasma and haemocytes of bivalve molluscs. Fish \& Shellfish Immunology 15, 275-282.

Maldonado, C., Bayona, J. M. and Bodineau, L., 1999. Sources, Distribution, and Water Column Processes of Aliphatic and Polycyclic Aromatic Hydrocarbons in the Northwestern Black Sea Water. Environment Science \& Technology 33, 2693 -2702.

Marchand, M. H., 1980. The Amoco Cadiz oil spill. Distribution and evolution of hydrocarbon concentrations in seawater and marine sediments. Environment International 4, 421-429.

McVeigh, A., Moore, M., Allen, J. I. and Dyke, P., 2006. Lysosomal responses to nutritional and contaminant stress in mussel hepatopancreatic digestive cells: A modelling study. Marine Environmental Research 62, 433-438.

Meador, J. P., Stein, J. E., Reichert, W. L. and Varanasi, U., 1995. Bioaccumulation of polycyclic aromatic hydrocarbons by marine organisms, in: Ware, G. W., Reviews of environmental contamination and toxicology, 79-166.

Morales-Caselles, C., Jiménez-Tenorio, N., González de Canales, M., Sarasquete, C. and DelValls, T., 2006. Ecotoxicity of Sediments Contaminated by the Oil Spill Associated with the Tanker "Prestige" Using Juveniles of the Fish Sparus aurata. Archives of Environmental Contamination and Toxicology 51, 652-660.

Reynaud, S., Duchiron, C. and Deschaux, P., 2004. 3-Methylcholanthrene induces lymphocyte and phagocyte apoptosis in common carp (Cyprinus carpio L) in vitro. Aquatic Toxicology 66, 307-318.

Sami, S., Faisal, M. and Huggett, R. J., 1992. Alteration in cytometric characteristics of hemocytes from the American oyster Crassostrea virginica exposed to a polycyclic aromatic hydrocarbon (PAH) contaminated environment. Marine Biology 113, 247-252.

Stehr, C. M., Myers, M. S., Johnson, L. L., Spencer, S. and Stein, J. E., 2004. Toxicopathic liver lesions in English sole and chemical contaminant exposure in Vancouver Harbour, Canada. Marine Environmental Research 57, 55-74.

Tronczynski, J., Munschy, C., Héas-Moisan, K., Guiot, N., Truquet, I., Olivier, N., Men, S. and Furaut, A., 2004. Contamination of the Bay of Biscay by polycyclic aromatic hydrocarbons (PAHs) following the T/V "Erika" oil spill. Aquatic Living Resources 17, 243-259.

Tujula, N., Radford, J., Nair, S. V. and Raftos, D. A., 2001. Effects of tributyltin and other metals on the phenoloxidase activating system of the tunicate, Styela plicata. Aquatic Toxicology 55, 191-201.

Van der Oost, R., Heida, H., Opperhuizen, A. and Vermeulen, N. P. E., 1991. Interrelationships between bioaccumulation of organic trace pollutants (PCBs, organochlorine pesticides and PAHs), and MFO-induction in fish. Comparative Biochemistry and Physiology Part C: Comparative Pharmacology 100, 43-47.

WHO, 1997. Non-heterocyclic polycyclic aromatic hydrocarbons. International Programme on Chemical Safety, Geneva. 202, pp.734.

Wootton, E. C., Dyrynda, E. A., Pipe, R. K. and Ratcliffe, N. A., 2003. Comparisons of PAH-induced immunomodulation in three bivalve molluscs. Aquatic Toxicology 65, 13-25. 
Yamaguchi, K., Near, R., Shneider, A., Cui, H., Ju, S. and Sherr, D. H., 1996. Fluoranthene-induced apoptosis in murine $\mathrm{T}$ cell hybridomas is independent of the Aromatic Hydrocarbon Receptor. Toxicology and Applied Pharmacology 139, 144-152. 